\section{Bjørn Angelsen 70 år}

I forbindelse med at professor emeritus Bjørn Angelsen fylte 70 år arrangerte Institutt for sirkulasjon og bildediagnostikk ved NTNU 15. juni 2017 et symposium for å hedre hans innsats i forskning og utvikling av medisinsk ultralyd gjennom mange tiår.

Historien om medisinsk ultralyd er tett knyttet til Bjørns karriere. Han er en av pionerene i utviklingen av Dopplerteknologien, og introduserte teknikken i klinisk praksis sammen med kardiolog Liv Hatle. I dag er Doppler et av de viktigste redskapene i kardiovaskulær diagnostikk både hos voksne pasienter og innen obstetrikk. Bjørns arbeid har inspirert mange kollegaer opp gjennom tiden, og hans innsats har vært startskuddet for flere ultralydselskaper, blant dem GE Vingmed Ultrasound, som i dag er ledende innen ultralyd hjerteavbildning.

Totalt var 60 kollegaer og gjester samlet på symposiet, og det ble presentert både historiske tilbakeblikk og smakebiter av dagens og framtidens ultralyd. Innledere på symposiet var blant annet Kjell Arne Ingebrigtsen, grunnlegger av Vingmed Ultrasound, Jon Lamvik, første professor ved Det Medisinske fakultet i Trondheim, Kjell

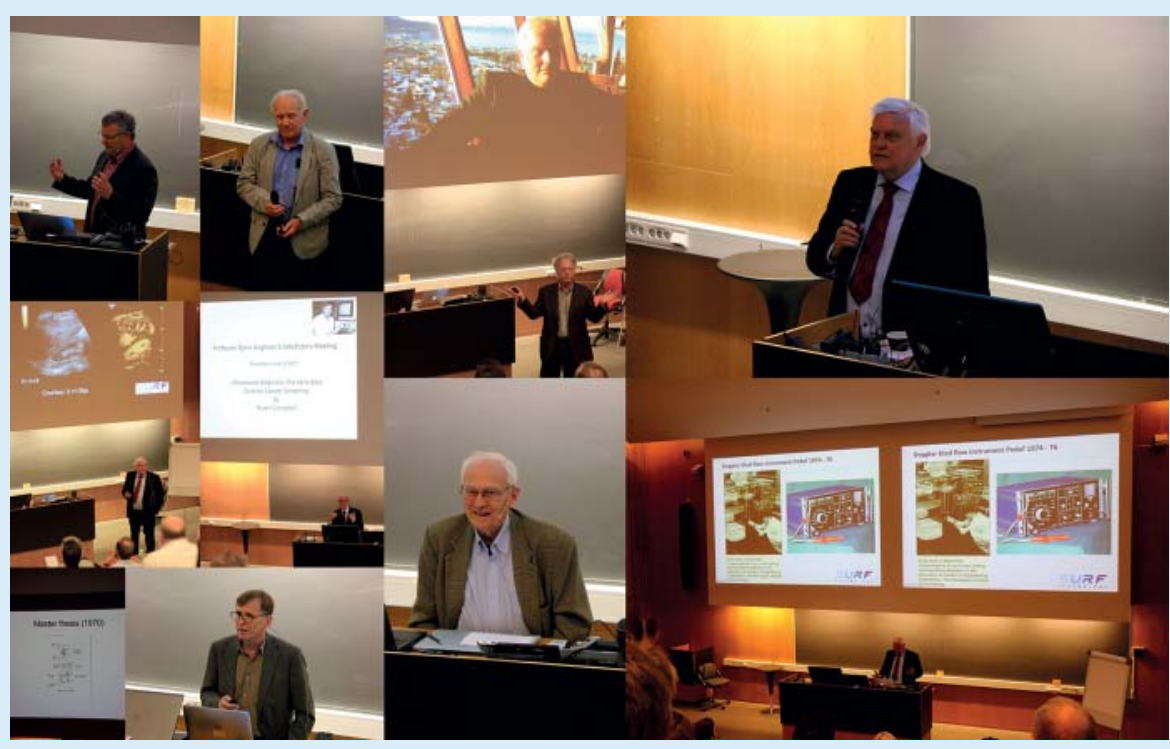

Symposium for Bjørn Angelsen

Kristoffersen, sjefingeniør hos GE Vingmed Ultrasound, Hans Torp, professor og leder av NTNUs ultralydgruppe, Sturla Eik-Nes, professor emeritus ved NTNU og tidligere seksjonsoverlege ved Nasjonalt senter for fostermedisin, Stuart Campbell, tidligere professor i obstetrikk og gynekologi ved St George's Hospital Medical School og en av pionerene innen obstetrisk bruk av ultralyd,
Peter Burns, professor ved The University of Toronto, Catharina Davies, professor ved Institutt for fysikk, NTNU, og naturligvis Bjørn selv. Han presenterte de siste framskrittene gruppa hans har gjort innen multifrekvens ultralyd og mulighetene for ikke-lineær vevskarakterisering, reverberasjonsundertrykkelse, åpning av blod-hjerne-barrieren og ultralydmediert medisinlevering. 